\title{
Mean Score and Correlation Research on Job Satisfaction at ABC Factory
}

\author{
Mohd Hafiz Mohammad Hamzah, Wan Noor Hayatie Wan Abdul Aziz, Nurul Husna Jamian, \\ Farah Waheeda Azhar, Siti Khatijah Nor Abd Rahim
}

\begin{abstract}
Job satisfaction issue had been discussed widely in organizational behavior field. An employee with a high job's satisfaction shows a superior quality of work and production compared to the one who does not. Our paper aims to study the job satisfaction among workers at $A B C$ factory. A set of questionnaire consists of two parts, which are background of respondent and job satisfaction components were distributed among 80 employees. The questionnaire consists of three main components which are work environment, productivity, and organization can be classified by 25 questions. Two statistical analysis applied to evaluate the collected data which are the mean score analysis and the correlation. The findings of the survey are then compared to define the level of job's satisfaction and its contributing factors among workers in ABC factory.
\end{abstract}

Keywords:: Job's satisfaction, mean score analysis, productivity, working environment.

\section{INTRODUCTION}

Nowadays, enlightening the worker productivity, providing a suitable working environment and good relationship between organizations in job satisfaction are major concerns of industry, especially in developing countries. Job satisfaction is a good indicator to boosts factory in attracting and retaining employees. Job satisfaction means "the degree to which employees are content with the job that they perform" [1]. Adverse environment and inappropriate management systems lead to reduce worker productivity and increase production cost. In recent years, the important factor in measuring employee productivity is employees who feel comfort with their profession, determined by the environment and the conditions in their workplace. In order to deal with the undercurrents of their business life, employers need to readjust themselves. A stumpy performance and industrial health illnesses occurs when people are working under inconvenient conditions. This will cause high level of absenteeism and increase the turnover rates among the employees [2]. Improving the conditions in their workplace somehow will improve the employees' engagement or disengagement such as complaints and absenteeism; meanwhile it will surely help to increase the productivity of the employees [3]. This study

Revised Version Manuscript Received on September 16, 2019.

Mohd Hafiz Mohammad Hamzah, Mathematics Department, Universiti Teknologi MARA, Perak Branch, Tapah Campus, Malaysia.

Wan Noor Hayatie Wan Abdul Aziz, Mathematics Department, Universiti Teknologi MARA, Perak Branch, Tapah Campus, Malaysia.

Nurul Husna Jamian, Statistics Department, Universiti Teknologi MARA, Perak Branch, Tapah Campus, Malaysia.

Farah Waheeda Azhar, Mathematics Department, Universiti Teknologi MARA, Perak Branch, Tapah Campus Malaysia.

Siti Khatijah Nor Abd Rahim, Computer Science Department, Universiti Teknologi MARA, Shah Alam, Malaysia. applies mean score and t-test to analyze the data collected among employee at $\mathrm{ABC}$ factory. There are five sections of this paper as follows. We begin with the introduction parts, followed by the related literature review. Next section explains the methodology, the results and the discussions and the last part is the conclusion.

\section{LITERATURE REVIEW}

Job satisfaction has been widely defined. A paper on a nurse's job satisfaction [4] suggested that job satisfaction is different from time to time according to current state or situation. It means we might hate our job at the beginning, however as time flies, our perception towards our job will also change and will improve our job satisfaction. This also supported by [5] who suggested that economic cycles can also affect the job satisfaction among workers and [6] which define job satisfaction as a study in organizational behavior with a different perception based on individual's experience. Industrial 4.0 which had taken place now, has created an intense of job's security among workers. The competition among workers are very high nowadays to secure their jobs.

To have a great level of job satisfaction, several factors need to be considered for both employee and employer sides such as the company demand, client's needs, environment situation and many more. As job satisfaction increases, the skills of the employee will also increase [6] which also create a highly motivated employee for the respected organization. This is the main reason why job satisfaction is very vital to every employee. Lots of factors contributing to job satisfaction have been revealed based on the recent research.

A paper by [4] did not identify individual factors such as age, gender, and education level related to job satisfaction. It is in contrast with [10] which suggested that the main factors to increase the level of job satisfaction is the role of the supervisor or leader of the group and their level of education. In [7] they suggested that a caring culture that comprehends the community relations, judgment's power, and mutual way of communication will help increase the job satisfaction among workers.

There are different levels of measurement between civil servant and private servant. A civil servants feel more valued by society, they are more likely to have higher levels of public service motivation, which will contribute to higher 
level of individual job satisfaction as compared to private servants who are most likely try to meet the company demand most of the time [8]. In addition, in [9] suggested that a different generation show a different demand on job satisfaction. They suggested that for a company to hire Gen Y workers, a more likely home-based working environment and techno-savvy equipment must be prepared since Gen Y expect the organization to be fortified with present machinery and clear direction by a company as Gen Y demand immediate feedback on their performance. This also supported by [10] that social media will also help to increase the level of job's satisfaction.

A working environment with a good relationship among workers, employer and employee, a home based workplace, an ergonomic workplace will motivate workers to work every day. It supports by [11], besides salary, job satisfaction will increase if the working environment is better. There are some factors contributing to the level of job satisfaction based on previous study, however we decide to focus on the productivity, working environment and organization.

\section{METHODOLOGY}

This study employed a dataset primarily collected among employees at ABC factory. A total of 80 employees were chosen as respondents of this study across various departments and different positions to answer the questionnaire to cover the major aspects of satisfaction on their jobs adopted from [12]. This is 4 Likert scale questionnaire where 1 is Strongly Dissatisfied (SD), 2 is Dissatisfied (D), 3 is Satisfied (S) and 4 is Strongly Satisfied (SS). The respondents were conveniently chosen once they are available to participate, delighted, eligible at the right time and place. A finding by [12] in a study done to investigate job satisfaction using exploratory factor analysis (EFA) identified three variables or components factors with regard to factors affecting job satisfaction, which are productivity, work environment and organization. Reliability test has been performed for each component by calculating Cronbach's Alpha value, and all components scored a value of greater than 0.6 which indicated each component has a reliable measure of consistency. Thus, this study was performed to investigate the employees' satisfaction level towards those three variables.

In the analysis part, a descriptive analysis using mean score was calculated by calculating the mean of each item within each variable using IBM SPSS version 25 in order to see the level of employees' productivity, satisfaction on work environment and organization. Then, a bivariate analysis is performed among those three variables to see the relationship between two variables such as productivity with work environment, productivity with organization and work environment with organization based on the proposed research model in Fig. 1.

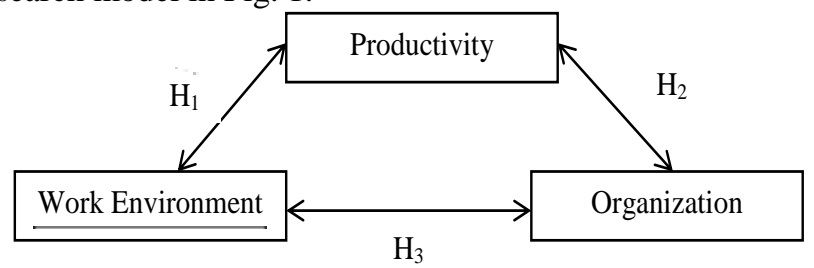

Fig. 1: Correlation of productivity, work environment and organization

Then, this study extended to investigate the correlation between three variables such Productivity, Work environment and Organization towards Job satisfaction. Fig. 2 shows the proposed research model.

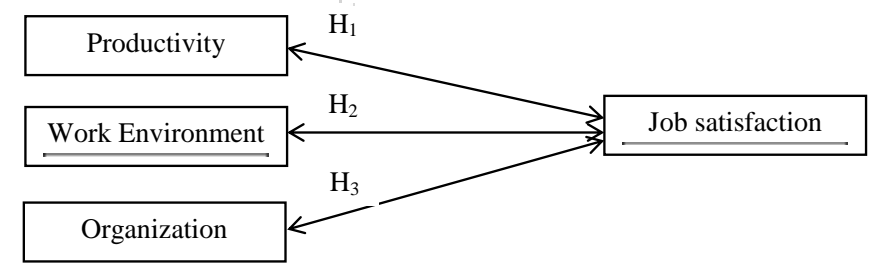

Fig. 2: Correlation of productivity, work environment and organization on job satisfaction

\section{RESULTS AND DISCUSSION}

\section{A. Mean score of productivity}

Based on Table 1, there are eight questions regarding the employees' productivity that concerned on clear goal and target setting, problem solver, productivity, able to sacrifice, quick response and action, and clear about the job scope. It showed that ABC Factory's employees had a high level of satisfaction on productivity. Most of them stated that they clearly defined quality goals, trained as good problem solver, always aims to achieve target quotas and goals, very productive, always try hard to respond quickly to fulfil customers' needs, have a purer path for career development and task necessities as well. However, it showed moderate level in solving a particular problem to make the customers satisfied. 
Table 1: Score mean of productivity

\begin{tabular}{|c|c|c|c|c|c|c|c|}
\hline & Item of Organization & SD (1) & $\mathbf{D}(\mathbf{2})$ & $\mathbf{S ~ ( 3 )}$ & $\mathbf{S S}(\mathbf{4})$ & Score Mean & Level \\
\hline 1. & I have all the equipment to perform my job. & 1 & 10 & 60 & 9 & 2.96 & Moderate \\
\hline 2. & $\begin{array}{c}\text { How pleased are you with your participation in } \\
\text { resolutions that mark your effort. }\end{array}$ & 0 & 2 & 69 & 9 & 3.09 & High \\
\hline 3. & $\begin{array}{c}\text { Are you satisfied with the information you receive } \\
\text { from your superior about any scenario happen in } \\
\text { the company? }\end{array}$ & 0 & 5 & 65 & 10 & 3.06 & High \\
\hline 4. & $\begin{array}{c}\text { Are you satisfied with your prospect to get a better } \\
\text { job in this company? }\end{array}$ & 1 & 3 & 56 & 20 & 3.19 & High \\
\hline 5. & $\begin{array}{c}\text { Fruitful time consumed occupied on the tasks } \\
\text { allocated to me. }\end{array}$ & 0 & 2 & 59 & 19 & 3.21 & High \\
\hline 6. & The whole quality of service that I deliver & 0 & 1 & 66 & 13 & 3.15 & High \\
\hline 7. & $\begin{array}{c}\text { Considering the whole thing, how pleased are you } \\
\text { with your career? }\end{array}$ & 1 & 4 & 57 & 18 & 3.15 & High \\
\hline
\end{tabular}

Note: SD=Strongly dissatisfied, D=Dissatisfied, S=Satisfied and SS=Strongly satisfied.

\section{B. Mean score of satisfaction towards work environment}

According to Work Environment as shown in Table 2, there are nine items asked that are related to the work environment. The results identified that good working environment provides better employees in term of performance and quality of works. Moreover, they had good respectful practice to preserve company good name and relationships among workers. Besides, they are also delighted on commitment given by the supervisors and senior manager, goal setting and communication opportunity. In directly, it drives the workers to work hard and fully utilized their skills and abilities for individual and company good performance. However, there is a moderate level of satisfaction on company's support and motivation in keeping employees informed about matters affecting the company.

Table 2: Mean score of satisfaction towards work environment

\begin{tabular}{|c|c|c|c|c|c|c|c|}
\hline & Item of Work Environment & SD (1) & D (2) & S (3) & SS (4) & Score Mean & Level \\
\hline 1. & $\begin{array}{c}\text { I feel very heartened to come up with fresh and } \\
\text { improved ways of doing things }\end{array}$ & 0 & 1 & 47 & 32 & 3.39 & High \\
\hline 2. & $\begin{array}{c}\text { The Company keep us inform about the company } \\
\text { current situation all the time if we might get } \\
\text { affected about it. }\end{array}$ & 1 & 13 & 62 & 4 & 2.86 & Moderate \\
\hline 3. & $\begin{array}{c}\text { I recognize why it is so vital for (Company name) } \\
\text { to value multiplicity (to identify and admiration the } \\
\text { value of variances in race, gender, age, etc. }\end{array}$ & 0 & 0 & 28 & 52 & 3.65 & High \\
\hline 4. & $\begin{array}{c}\text { My skills and abilities are applied widely at my } \\
\text { job. }\end{array}$ & 0 & 1 & 46 & 33 & 3.40 & High \\
\hline 5. & $\begin{array}{c}\text { My supervisor's shows a very good commitment to } \\
\text { quality works. }\end{array}$ & 0 & 3 & 52 & 25 & 3.28 & High \\
\hline 6. & $\begin{array}{c}\text { Senior managers noticeably prove an obligation } \\
\text { towards quality. }\end{array}$ & 1 & 1 & 61 & 17 & 3.18 & High \\
\hline 7. & $\begin{array}{c}\text { Are you satisfied with the information you receive } \\
\text { from your superior about the situation in your } \\
\text { division? }\end{array}$ & 1 & 5 & 67 & 7 & 3.00 & High \\
\hline 8. & $\begin{array}{c}\text { The ABC Factory clearly talks about its goals and } \\
\text { policies to me }\end{array}$ & 0 & 4 & 58 & 18 & 3.18 & High \\
\hline 9. & $\begin{array}{c}\text { I obtain adequate chance to intermingle with other } \\
\text { employees on a proper level. }\end{array}$ & 0 & 5 & 60 & 15 & 3.03 & High \\
\hline
\end{tabular}

\section{Note: $S D=$ Strongly dissatisfied, $D=$ Dissatisfied, $S=$ Satisfied and $S S=$ Strongly satisfied.}

\section{Mean score satisfaction towards organization}

According to Table 3, overall there are seven items classified under Organization component. The results described the workers had high satisfaction with decisions made by the organization because it allows some opinions from workers. It also showed that workers were satisfied with current information disseminated by the organization and the company opportunity for better position as well. In addition, the workers had high pleasure with the time given to finish their job. However, they had moderate satisfaction on organization related to the tools and resources provided to make their works running smooth. Overall, it was found that the entire worker had satisfied with their job. 
Table 3: Mean score of satisfaction towards organization

\begin{tabular}{|c|c|c|c|c|c|c|c|}
\hline & Item of Organization & SD (1) & $\mathbf{D}(\mathbf{2})$ & $\mathbf{S}(\mathbf{3})$ & $\mathbf{S S}$ (4) & $\begin{array}{c}\text { Score } \\
\text { Mean }\end{array}$ & Level \\
\hline 1. & I have all the equipment to perform my job. & 1 & 10 & 60 & 9 & 2.96 & Moderate \\
\hline 2. & $\begin{array}{c}\text { How pleased are you with your participation in } \\
\text { resolutions that mark your effort. }\end{array}$ & 0 & 2 & 69 & 9 & 3.09 & High \\
\hline 3. & $\begin{array}{c}\text { Are you satisfied with the information you } \\
\text { receive from your superior about any scenario } \\
\text { happen in the company? }\end{array}$ & 0 & 5 & 65 & 10 & 3.06 & High \\
\hline 4. & $\begin{array}{c}\text { Are you satisfied with your prospect to get a } \\
\text { better job in this company? }\end{array}$ & 1 & 3 & 56 & 20 & 3.19 & High \\
\hline 5. & $\begin{array}{c}\text { Fruitful time consumed occupied on the tasks } \\
\text { allocated to me. }\end{array}$ & 0 & 2 & 59 & 19 & 3.21 & High \\
\hline 6. & The whole quality of service that I deliver & 0 & 1 & 66 & 13 & 3.15 & High \\
\hline 7. & $\begin{array}{c}\text { Considering the whole thing, how pleased are } \\
\text { you with your career? }\end{array}$ & 1 & 4 & 57 & 18 & 3.15 & High \\
\hline
\end{tabular}

Note: $S D=$ Strongly dissatisfied, $D=$ Dissatisfied, $S=$ Satisfied and $S S=$ Strongly satisfied.

\section{Correlation analysis}

Correlation analyses were carried out to examine the strength of the relationships between independent variables which are Productivity, Work Environment and Organization. Based on Table 4, it was revealed that Productivity has significant positive relationship with Work
Environment $(\mathrm{r}=0.312, \mathrm{p}<0.05)$ same goes between Productivity and Organization $(r=0.411, p<0.05)$. There was also a significant correlation between Work Environment and Organization $(\mathrm{r}=0.488, \mathrm{p}<0.05)$. Therefore, the hypotheses proposed in this study (H1 to H3) are accepted as shown in Fig. 1.

Table 4: Correlation of productivity, work environment and organization

\begin{tabular}{|c|c|c|c|c|}
\hline & & Productivity & Work Environment & Organization \\
\hline \multirow{3}{*}{ Productivity } & Pearson Correlation & 1 & 0.312 & 0.411 \\
\cline { 2 - 5 } & Sig. (2 tailed) & & $0.005^{* *}$ & $0.000^{* * *}$ \\
\hline \multirow{2}{*}{ Work Environment } & Pearson Correlation & 0.312 & 1 & 0.488 \\
\cline { 2 - 5 } & Sig. (2 tailed) & $0.005^{* * *}$ & & $0.000^{* * *}$ \\
\hline \multirow{2}{*}{ Organization } & Pearson Correlation & 0.411 & 0.488 & 1 \\
\cline { 2 - 5 } & Sig. (2 tailed) & $0.000^{* * *}$ & $0.000^{* * *}$ & 1 \\
\hline
\end{tabular}

Note: *** Correlation is significant at 0.05 level ( 2 tailed)

Table 5 displays the correlation results obtained between the predictors and response variable. It was found that there are significant correlation between Productivity and Job Satisfaction $(\mathrm{r}=0.279, \mathrm{p}<0.05)$, Work Environment and Job
Satisfaction $(\mathrm{r}=0.302, \mathrm{p}<0.05)$, and Organization and Job Satisfaction $(r=0.411, p<0.05)$. Therefore, the hypotheses proposed in this study (H1 to $\mathrm{H} 3$ ) are accepted as shown in Fig. 2.

Table 5: Correlation of productivity, work environment and organization on job satisfaction

\begin{tabular}{|c|c|c|c|c|}
\hline & & Productivity & Work Environment & Organization \\
\hline \multirow{2}{*}{ Job satisfaction } & Pearson Correlation & 0.279 & 0.302 & 0.411 \\
\cline { 2 - 5 } & Sig. (2 tailed) & $0.012^{* * *}$ & $0.007 * * *$ & $0.000^{* * *}$ \\
\hline
\end{tabular}

Note: *** Correlation is significant at 0.05 level $(2$ tailed $)$

\section{CONCLUSION}

Three main aspects are being investigated in our research regarding the job satisfaction among workers in $\mathrm{ABC}$ factory which are the productivity, the working environment and the organization. The mean score analysis had shown a very positive level of satisfaction among the workers of $\mathrm{ABC}$ Factory towards the productivity level, their working environment, and also the organization.

This shows that all the workers of ABC Factory are satisfied with their current environment at their workplace. The correlation analysis also shows a significant correlation between all the variables. In conclusion, we can say that the job satisfaction among $\mathrm{ABC}$ Factory are very high due to their satisfaction off their productivity level, working environment and their organization.

\section{ACKNOWLEDGEMENT}

We would like to express our appreciation to our Faculty of Computer and Mathematical Sciences, Universiti Teknologi MARA Perak Branch, Tapah campus, our family, Madam Raja Nur Zalikha Raja Akram from ABC factory and 
to all of our colleagues for their direct or indirectly contribution in our research.

\section{REFERENCES}

1. J. J. Phillips and A. O. Connel, Managing Employee Retention: A Strategic Accountability Approach. Oxford: Butterworth-Heinemann, 2003.

2. L. Demet, "Impact of workplace quality on employee productivity: Case study of a bank in Turkey," Journal of Business, Economic and Finance, 1(1), 2012, pp. 38-49.

3. P. Roeloelofsen, "The impact of office environments on employee Performance: The design of the workplace as a strategy for productivity enhancement," Journal of Facilities Management, 1(3), 2002, pp. 247 - 264.

4. D. R. Alison, M. D. Ibo, and D. V. Melissa, "Job satisfaction among critical care nurses: A systematic review," International Journal of Nursing Studies, 88, 2018, pp. 123-134.

5. O. Ravid, M. Malul, and R. Zultan, "The effect of economic cycles on job satisfaction in a two-sector economy," Journal of Economic Behavior and Organization, 138, 2017, pp. 1-9.

6. F. Y. Kum, S. L. Hui, and Z. Qingji, "Determinants of job satisfaction and performance of seafarers," Transportation Research Part A: Policy and Practice, 110, 2018, pp. 1-12.

7. M. Juan and K. B. Bruce, "The impact of organizational culture and leadership performance on PR professionals' job satisfaction: Testing the joint mediating effects of engagement and trust," Public Relations Review, 45(1), 2019, pp. 64-75.

8. S. S. Brent, C. P. John, and B. Evan, "Job satisfaction in Cascadia: A comparison of British Columbia, Oregon, and Washington civil servants," Social Science Journal, 54(4), 2017, pp. 379-388.

9. N. Daud, "Determinants of job satisfaction: How satisfied are the new generation employees in Malaysia?," Procedia - Social and Behavioral Sciences, 219, 2016, pp. 208-213.

10. C. Fulvio and V. Clara, "Internet use and job satisfaction," Computers in Human Behavior, 90, 2019, pp. 141-152.

11. W. J. Kent, L. Ye, and S. Thomas, "Entrepreneurs innovation bringing job satisfaction, work-family balance, and life satisfaction: In China and around the world," International Journal of Innovation Studies, 1(4), 2017, pp. 193-206.

12. W. N. H. Wan Abdul Aziz, F. Zulkipli, M. H. Mohammad Hamzah, F. W. Azhar, and S. K. N. A. Rahim, "Investigating job satisfaction using exploratory factor analysis at $\mathrm{ABC}$ factory," International Journal of Engineering and Technology (UAE), 7(4.33), 2018, pp. 56-59. 